Al-BayyinaH: ISSN: 1979-7486 (p); 2580-5088(e)

Vol. 3 No. 1 Tahun 2019, p. 1-14

\title{
Fiqh Perempuan Keindonesiaan
}

\author{
Lahaji $^{1}$, Sulaiman Ibrahim ${ }^{2}$ \\ IAIN Sultan Amai Gorontalo, Jl. Sultan Amai, Limboto, Gorontalo \\ Email: 11ahaji@iaingorontalo.ac.id; dan ${ }^{2}$ sulaiman@iaingorontalo.ac.id
}

\begin{abstract}
:
Women have more value than men. Women are bestowed with their feminine status that distinguishes them from men. The distinctive characteristics of women, who can get pregnant, give birth, and breastfeed, love, fortitude, and patience in educating children are the advantages of women. This article discusses women's fiqh in several concepts of meaning. First, women's figh is amaliyah laws in implementing Shari'a, for example the issue of marriage guardianship for women who want to carry out marriage. Second, women's fiqh is the arguments about the law regarding, for example, the proposition of women's leadership. From these two meanings, it was formulated that women's figh is an understanding of the law and the arguments relating to women in carrying out activities. Because women's fiqh is related to sharia law and thenaqli and aqli arguments, essentially women's fiqh in the sense of understanding the existence of women is the result of ijtihad called fiqh ijtihadiy. Therefore, it is not surprising that in understanding a legal object, the results of understanding (fiqh) produced by a mujtahid sometimes conflict with or differ from understanding (fiqh) obtained by other mujtahids.
\end{abstract}

Keywords: Fiqh-Women-Indonesia.

\section{Abstrak:}

Perempuan memiliki nilai lebih dibandingkan lelaki. Perempuan dianugrahkan dengan status keperempuanannya yang membedakannya dengan lelaki. Ciri khas perempuan yang dapat hamil, melahirkan, dan menyusui, kasih sayang, ketabahan, dan kesabaran dalam mendidik anak merupakan kelebihan perempuan. Artikel ini membahas tentang fiqh perempuan dalam beberapa konsep makna. Pertama, fiqh perempuan adalah hukum-hukum amaliyah dalam melaksanakan syariat, misalnya masalah wali nikah bagi kaum perempuan yang hendak melaksanakan perkawinan. Kedua, fiqh perempuan adalah dalil-dalil tentang hukum tentang, misalnya dalil tentang kepemimpinan kaum perempuan. Dari dua pengertian ini, maka dirumuskan bahwa fiqh perempuan adalah pemahaman terhadap hukum dan dalil yang berkenaan kaum perempuan dalam melakukan aktivitas. Karena fiqh perempuan berkaitan dengan hukum syarah' dan dalil naqli maupu naqli, maka secara esensial fiqh perempuan dalam artian pemahaman tentang eksistensi kaum perempuan merupakan hasil ijtihad yang disebut dengan fiqh ijtihädiy. Oleh karena itu, tidak diherankan jika dalam memahami suatu objek hukum, hasil pemahaman (fiqh) yang dihasilkan oleh seorang mujtahid terkadang bertentangan dengan dan atau berbeda dengan pemahaman ( $f i q h$ ) yang diperoleh mujtahid lainnya.

Kata Kunci: Fiqh-Perempuan-Indonesia. 


\section{Pendahuluan}

Tatanan kehidupan umat manusia yang didominasi kaum laki-laki atas kaum perempuan sudah menjadi akar sejarah yang panjang. Tatanan itu, perempuan ditempatkan sebagai the second human being (manusia kelas dua), yang berada di bawah superioritas laki-laki, dan akhirnya membawa implikasi luas dalam sosial masyarakat.

Beribu tahun sebelum Islam, perempuan dipandang tidak memiliki kemanusiaan yang utuh, dan oleh karenanya tidak bersuara, berkarya, dan berharta. Kemudian setelah Islam datang, agama ini secara bertahap mengangkat kaum perempuan, sehingga mereka berhak menyuarakan keyakinan, berhak mengaktualisasikan karya, dan berhak memiliki harta yang memungkinkan mereka diakui sebagai warga masyarakat. Kedudukan perempuan seperti yang terakhir disebutkan, mengindikasikan bahwa salah satu misi ajaran Islam sejak kehadirannya, adalah tidak memberikan keutamaan kepada jenis kelamin tertentu.

Berkaitan dengan itu, maka fiqh Islam memandang bahwa setiap orang dalam beraktivitas menghindarkan pembedaan jenis kelamin dan suku bangsanya. Pemahaman fiqh seperti ini, kelihatannya sejalan dengan UU HAM dalam konteks kekinian dan keindonesiaan yang di dalamnya terdapat aturan khusus tentang hak kaum perempuan. ${ }^{1}$ Secara umum, UU HAM tersebut telah mencerminkan fiqh yang relevan dengan era kekininan, terutama dalam konteks keindonesiaan. Bahkan, ada suatu hal yang menarik yakni pengakuan UU HAM terhadap fiqh Islam tentang perlunya wali bagi perempuan yang belum dewasa dan belum menikah.

Di sisi lain, fiqh klasik dinyatakan bahwa perempuan tidak berhak menjadi pemimpinan. Pemahaman fiqh klasik ini menjadi kontra dengan pemahaman fiqh era kekinian di mana perempuan di berbagai negara 
Lahaji dan Sulaiman Ibrahim:

"Fiqh Perempuan Keindonesiaan"

banyak yang tampil sebagai pemimpin, ${ }^{2}$ bahkan dalam konteks keindonesiaan kepemimpinan kaum perempuan pada skala dominan diperbolehkan.

Berkaitan dengan latar belakang yang telah diuraikan, maka sangat menarik untuk dikaji lebih lanjut tentang bagaimana fiqh perempuan, kekininan dan keindonesiaan. Untuk lebih mendalamnya kajian ini, maka sub permasalahan yang dijadikan objek pembahasan adalah, apa yang dimaksud fiqh perempuan dan bagaimana konsepnya di era kekininan dalam konteks keindonesiaan.

\section{Pembahasan}

\section{Pengertian Fiqh Perempuan}

Dari segi bahasa, perkataan fiqh (Indonesia: fikih) berasal dari akar kata $f \bar{a}, q \bar{a} f$, dan $h \bar{a}$ (فق) yang berarti paham atau pengetahuan tentang sesuatu. ${ }^{3}$ Dari sini dapat ditegaskan bahwa perkataan fiqh itu menunjuk kepada pengetahuan tentang hukum agama, hukum-hukum syariat (knowledge of the law), salah satu doa yang menyatakan : اللهم فقفه فى الدين 4 (ya Allah, ajarkanlah padanya pengetahuan agama dan jadikanlah dia memahami segala perkara yang sulit).

Kemudian secara istilah, pengertian fiqh tidak jauh berbeda dengan pengertian secara bahasa sebagaimana yang disebutkan tadi. Abū Zahrah mendefinisikan fiqh sebagai ilmu tentang hukum-hukum syariat yang bersifat amaliyah, yang diambil dari dalil-dalilnya yang terperinci. ${ }^{5}$ Dengan

\footnotetext{
${ }^{2}$ Mereka misalnya, Cory Aquinto di Filipina, Benazir Bhuto di Pakistan, Gloria Arroyo Macapagal di Filipina, atau Sirimanvo Bandaranaike di Sri Langka.

${ }^{3}$ Lihat Abū Husain Ahmad bin Fāris bin Zakariyah, Maqāyis al-Lughah, juz IV (Bairūt: Dār al-Jail, 1981), h. 442

${ }^{4}$ Demikian doa Nabi saw yang ditujukan kepada sahabatnya, Ibn 'Abbās, dan para mufaqqih berpendapat bahwa doa tersebut ditujukan juga kepada ahli fiqh. Doa tersebut dapat dijumpai dalam Abū Ahmad Muhammad bin Hanbal, Musnad Ahmad dalam CD. Rom Hadīśs al-Syarīf al-Kutub al Tis'ah, Kitab Maktabat al-Hadīśs al-Syarīfah hadis nomor 2391.

${ }^{5}$ Abū Zahrah, Ushūl al-Fiqh (Mesir: Dār al-Fikr al-'Arabiy, t.th), h. 7
} 
demikian objek fiqh ada dua. Pertama, hukum-hukum amaliyah (perbuatan jasmaniah). Kedua, dalil-salil tentang hukum perbuatan itu.

Batasan yang akurat tentang fiqh perempuan, maka indikator perempuan lebih awal perlu diketahui. Perempuan dalam terminologi Arab seringkali disinonimkan dengan term (al-unśā, al-nis ā, imra'ah). ${ }^{6}$ Term al-unśa bermakna lembek dan lunak, sebagai lawan dari kata al-zakara yang berarti kuat. Perempuan disebut unśā, karena pada umumnya kulit mereka lembek atau lunak. Selanjutnya, term al-nisā sama dengan kata niswah asal katanya adalah nasiya yang berarti "lupa", atau “menghibur". Perempuan disebut al-nisā karena pada umumnya mereka pelupa, dan dikatakn niswah karena mereka pandai menghibur dirinya, terutama suaminya. Penggunaan term al-nis $\bar{a}$ atau niswah merujuk pada kaum perempuan secara umum, termasuk yang berstatus istri, janda, gadis, dan anak-anak. Sedangkan term imra'ah berasal dari kata mir'ah yang artinya cermin. Ini berarti bahwa perempuan pada umumnya suka bercermin, atau suka menghias diri di hadapan cermin, dan sesuai kenyataannya term imra'ah tersebut lebih cocok digunakan untuk menyebut perempuan gadis, perempuan mudah yang sudah bersuami, dan janda, karena mereka inilah yang lebih suka menghias diri.

Dalam Kamus Besar Bahasa Indonesia, perempuan diartikan sebagai perempuan dewasa, ${ }^{7}$ yakni orang yang mempunyai puki, dapat menstruasi, hamil, dan melahirkan anak. Tampak pengertian ini lebih melihat kepada aspek fisik perempuan. Pengertian perempuan yang lebih luas dikemukakan oleh Adil Athi Abdullah yaitu makhluk Allah swt. yang mulia, pasangan lelaki, yang dilebihkan oleh Allah dengan ciri kehamilan, melahirkan, dan menyusui, serta ketajaman kejiwaan seperti kasih sayang yang tinggi, kesabaran yang dalam mendidik anak, serta kelembutan jiwa.

${ }^{6}$ Lihat Ahmad Warson al-Munawwir, Kamus al-Munawwir Arab Indonesia, Edisi II, Cet XXV (Surabaya: Pustaka Progressif, 1997), h. 1417

${ }^{7}$ Departemen Pendidikan dan Kebudayaan, Kamus Besar Bahasa Indonesia (Cet. III; Jakarta: Balai Pustaka, 1994), h. 1125 
Dengan demikian, perempuan memiliki nilai lebih dibandingkan lelaki. Allah swt telah menganugerahkan kelebihan-kelebihan kepada perempuan berkaitan dengan status keperempuanannya yang membedakannya dengan lelaki. Ciri khas perempuan yang dapat hamil, melahirkan, dan menyusui, kasih sayang, ketabahan, dan kesabaran dalam mendidik anak merupakan kelebihan perempuan.

Berdasar pada batasan-batasan pengertian yang telah dikemukakan, maka dalam pandangan penulis bahwa, fiqh perempuan memiliki beberapa konsep makna. Pertama, fiqh perempuan adalah hukum-hukum amaliyah dalam melaksanakan syariat, misalnya masalah wali nikah bagi kaum perempuan yang hendak melaksanakan perkawinan. Kedua, fiqh perempuan adalah dalil-dalil tentang hukum tentang, misalnya dalil tentang kepemimpinan kaum perempuan. Dari dua pengertian ini, maka dirumuskan bahwa fiqh perempuan adalah pemahaman terhadap hukum dan dalil yang berkenaan kaum perempuan dalam melakukan aktivitas.

Karena fiqh perempuan berkaitan dengan hukum syarah' dan dalil naqli maupun aqli, maka secara esensial fiqh perempuan dalam artian pemahaman tentang eksistensi kaum perempuan merupakan hasil ijtihad yang disebut dengan fiqh ijtihädiy. Oleh karena itu, tidak diherankan jika dalam memahami suatu objek hukum, hasil pemahaman (fiqh) yang dihasilkan oleh seorang mujtahid terkadang bertentangan dengan dan atau berbeda dengan pemahaman (fiqh) yang diperoleh mujtahid lainnya.

Dengan batasan seperti di atas, dapat dirumuskan bahwa fiqh perempuan di era kekinian bisa saja berbeda dengan fiqg perempuan masa klasik. Di sisi lain, fiqh perempuan di negara Arab berbeda dengan fiqh perempuan di Indonesia. Perbedaan seperti ini adalah sesuatu yang wajar mengingat sifat fiqh adalah elastis dan terkondisi karena ia lahir dari ijtihad.

Dalam pandangan Hamkah Haq, fiqh dengan syariat sungguh berbeda. Syariat dalam arti nash-nash yang mengandung hukum adalah 
berasal dari Allah, sedangkan fiqh sebagai upaya memahami hukum berasal dari mujtahid. Jika syariat bersifat mutlak dan universal berlaku untuk segala zaman dan tempat, maka fiqh sebagai pemahaman dan penafsiran dari syariat tentunya bersifat relatif, karena lahir dari ijtihad ulama sesuai dengan potensinya serta konteks dan kondisi zaman dan lingkungannya. ${ }^{8}$ Konsep fiqh yang dirumuskan ini, kelihatannya mendapat pembenaran dari sejarah karena dalam fiqh Islam, ijtihad yang merupakan penggunaan nalar dalam memahami dan menetapkan hukum, telah ada sejak permulaan Islam, dan berlanjut di zaman sahabat, kemudian mengalami perkembangan dari masa ke masa sampai era kekinian.

\section{Konsep Fiqh Perempuan di Era Kekininan dalam Konteks Keindonesiaan}

Empat sumber yang dijadikan sebagai acuan utama sebagai produk pemikiran Islam, yakni fiqh, fatwa ulama, yurispundensi, dan perundangundangan Islam. Fiqh sebagai produk ijtihad adalah sesuatu yang mutlah adanya. Dengan demikian, tidak dapat dipungkiri bahwa mengabaikan fiqh, termasuk pengabaian terhadap fiqh perempuan sama halnya dengan mengabaikan setengah dari konsep ajaran Islam. Dikatakan demikian, karena ajaran Islam yang termaktub dalam sumber pokoknya (Alquran dan Hadis), senantiasa menyebut eksistensi kaum perempuan. Eksistensinya ini, menyangkut perlunya mendudukkan perempuan pada kedudukan yang sebenarnya, serta memberi mereka peranan bukan saja dalam kehidupan rumah tangga, tetapi juga dalam kehidupan bermasyarakat.

\section{a) Fiqh Perempuan dalam Kehidupan Rumah Tangga}

Dalam Islam, kehidupan suami isteri merupakan hubungan kerja sama kedua bela pihak untuk mewujudkan kehidupan yang mawaddah wa rahmah (penuh cint dan kasing sayang), juga sakinah (ketenangan). Dalam mewujud-kan kehidupan tersebut, Alquran memberikan petunjuk bagi suami

\footnotetext{
${ }^{8}$ Hamka Haq, Syariat Islam; Wacana dan Penerapannnya (Cet. II; Makassar: Yayasan Ahkam, 2003), h. 27-28
} 
isteri. Bagi suami ada petunjuk seperti yang dalam QS. al-Nisā (4): 19, yakni, وَعَانُشِرُوهُنَّ بِالََْعْرُوفِ (dan pergauliah mereka/isteri-isteri dengan cara yang ma'ruf). ${ }^{9}$ Bagi isteri ada petunjuk seperti yang terdapat dalam QS. alBaqarah (2): 228, yakni, وَلَهُنَّ مِنْلُ الَّذِي عَلَيْهِنَّ بِالْتَعْرُوف (dan para perempuan mem-punyai hak yang setimpal dengan kewajibannya dengan cara-cara yang ma'rif). ${ }^{10}$ Dengan ayat ini, ditegaskan bahwa hubungan suami harus berdasarkan mu'āsyarah bi al-ma'rūf.

KH. Hussein Muhammad dalam bukunya Fiqh Perempuan mendefinisikan mu'āsyarah bi al-ma'rūf sebagai "pergaulan, pertemanan, persahabatan, kekeluargaan, dan kekerabatan yang dibangun bersama (antara suami isteri) dengan cara-cara yang baik. ${ }^{11}$ Prinsip mu'asyarah bi al-ma'rūf, persoalan-persoalan yang timbul dalam urusan rumah tangga bisa terselesaikan dengan baik.

Namun dalam kenyataannya di era kekininan yang sering terjadi di dalam rumah tangga kaum muslim Indonesia, suami dianggap sebagai orang yang mempunyai posisi tertinggi dalam pengambilan keputusan. Ia harus diutamakan dalam banyak hal, dan isteri (perempuan) harus taat kepada segala ketentuannya. Jika ia berusaha untuk melanggar, ia akan dikenakan sanksi nusyūz.

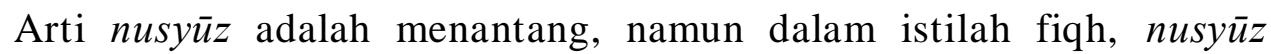
adalah ketidakpedulian atau pembangkangan isteri terhadap suami. Ringkasnya, nusyūz mencakup segala sesuatu yang tidak disukai suami. Sehingga, wajah seorang isteri yang kurang ceria di hadapan suami juga dianggap sebagai salah satu bentuk nusyūz. Dalam konteks nusyūz ini, menjadi semacam pembenaran dari sikap sewenang-sewenang suami terhadap isterinya. Karena demikian halnya, maka perlu dipahami fiqh kekinian tentang nusyūz.

\footnotetext{
${ }^{9}$ Departemen Agama RI, Al-Qur'an dan Terjemahnya (Jakarta: Proyek Pengadaan Kitab Suci al-Qur'an, 1992), h. 119

${ }^{10}$ Ibid., h. 55

${ }^{11}$ KH. Hussein Muhammad, Fiqh Perempuan (Yogyakarta: LkiS, 2001), h. 107
} 
Fiqh kekinian tentang nusyūz terutama dalam konteks fiqh keindonesiaan, kelihatanya harus dimasukkan dalam RUU tentang Kekerasan di Rumah Tangga dengan mengacu pada sikap ma'rüf yang telah singgung oleh ayat. Di samping itu, banyak ayat dalam Alquran yang menjelaskan betapa Allah menganjurkan sikap ma'rūf dalam perkawinan. Kekerasan terhadap isteri justerui bertentangan dengan konsep dengan mu'asyarah bi al-ma'rūf. Lagi pula, apakah mungkin Allah swt yang Maha Adil akan membiarkan tidak adil dan kekerasan terhadap sebagian makhluknya?

Karena itu, fiqh perempuan yang diharapkan di era kekinian adalah memberikan peluang yang sama secara proporsional kepada jenis perempuan dan laki-laki untuk memperoleh hak-hak dan kewajiban yang seimbang (adil) dalam kehidupannya. Tak ada jenis yang harus menempati posisi pertama dan kedua, sebab semuanya sama derajat dan martabatnya di hadapan Allah.

Masalah lain yang perlu mendapat perhatian di era kekinian dan masih kontroversial dalam masyarakat Indonesia kaitannya dengan fiqh perempuan, adalah tentang ijbār dan wali mujbir. Literatur fiqh klasik dikenal istilah wali mujbir yang dalam hal ini, adalah ayah atau kakek dari seorang gadis. Wali mujbir mempunyai hak ijbār atau hak memaksanakan sebuah perkawinan pada gadis tersebut. Gadis yang tidak mau mengikuti perkawinan tersebut akan dicap durhaka dan telah berbuat dosa. Dengan aturan ini, tidak mengherangkan masih banyak perempuan Indonesia, terutama di pedesaan menerima saja bentuk perkawinan itu. Dalam kenyataannya pula, sering perempuan tidak berdaya menghadapi pilihan orang tuanya, mesi mereka tidak menginginkannya.

Dalam KHI (Kompilasi Hukum Islam) dikatakan bahwa "yang bertindak sebagai wali nikah ialah seorang laki-laki yang memenuhi syarat hukum Islam, yakni muslim, aqil dan balig". ${ }^{12}$ Kemudian dalam pelaksanaannya, akad nikah atau ijab dan qabul, penyerahannya dilakukan

${ }^{12}$ Lihat Kompilasi Hukum Islam, pasal 20, ayat (1) 
oleh wali mempelai perempuan atau yang mewakilinya, dan qabul (penerimaannya) oleh mempelai laki-laki. Namun, Undang-undang perkawinan tidak mengatur tentang wali nikah secara eksplisit. Hanya dalam Pasal 26 ayat (1) dinyatakan:

"Perkawinan yang dilangsungkan dimuka Pegawai Pencatat Nikah yang tidak berwenang, wali nikah yang tidak sah, atau yang dilangsungkan tanpa dihadiri oleh 2 (dua) orang saksi dapat dimintakan pembatalannya oleh para keluarga dalam garis keturunan lurus ke atas dari suami isteri, jaksa dan suami atau isteri".

Jadi secara implisit bunyi pasal di atas mengisyaratkan dengan jelas bahwa perkawinan yang tidak diikuti wali, maka perkawinannya batal atau dapat dibatalkan. Namun demikian, apabila ternyata mereka yang melangsungkan perkawinan telah hidup bersama sebagai suami istri, maka hak untuk membatalkannya menjadi gugur. Hal ini sejalan dengan ketentuan fiqh Islam yang dipahami selama ini, yakni fiqh mazhab Syafi'i yang mayoritas dianut oleh masyarakat Indonesia. ${ }^{13}$

Persoalannya kemudian, bagaimana kalau seorang perempuan (gadis) menolak dinikahkan karena alasan ingin melanjutkan pendidikan ke jenjang yang lebih tinggi, ingin berkarir dulu, atau hal semacam itu. Bolehkah ia menolak pernikahan yang dirancang orangtuanya karena alasan-alasan tadi? atau mungkin si gadis mau menikah tapi bukan dengan laki-laki pilihan orang tuanya. Apakah dalam hal ini ia boleh menentukan sendiri calon suaminya?

Pertanyaan-pertanyaan di atas penting jika dirumuskan melalui fiqh perempuan, dan dihubungkan dengan realitas masyarakat kekininan di mana seorang anak perempuan mempunyai peluang lebih besar untuk mengenal dunia lain selain dunia yang ditawarkan orang tuanya. Si gadis mungkin mempunyai prinsip hidup dan pilihan yang berbeda dengan orang tuanya,

\footnotetext{
${ }^{13}$ Siti Musda Mulia, Muslimah Reformis, Perempuan Pembaru Keagamaan (Cet. I; Bandung; Mizan, 1425 H/ 2005 M), h. 359.
} 
termasuk dalam urusan perkawinan untuk membangun kehidupan rumah tangga bahagia.

\section{b) Fiqh Perempuan dalam Kehidupan Masyarakat}

Yang seringkali menjadi sorotan terhadap kaum perempuan di era kekinian, adalah masalah kepemipinan mereka di tengah-tengah masyarakat. Alquran dan hadis memang ada dalil yang dipahami sebagai ajaran bahwa kaum laki-laki itu pemimpin kaum perempuan. Tetapi hal ini menjadi kontroversial, sehingga memerlukan konsep fiqh yang lebih sesuai dengan kondisi berkembang di era kekinian.

Ayat Alquran yang sering dijadikan wacana kontroversial adalah QS. al-Nisa (4): 34, yakni :

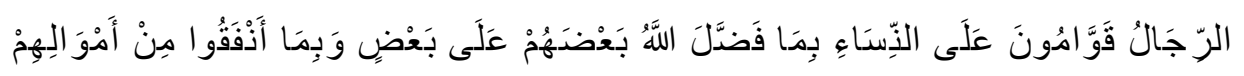

Terjemahnya :

Kaum laki-laki itu adalah pemimpin bagi kaum perempuan, oleh karena Allah telah melebihkan sebahagian mereka (laki-laki) atas sebahagian yang lain (perempuan), dan karena mereka (laki-laki) telah menafkahkan sebagian dari harta mereka.

Kemudian dalam hadis dinyatakan:

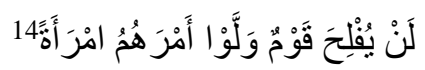

Artinya:

Tidak akan beruntung suatu kaum yang menyerahkan kepemimpinan meraka pada perempuan.

Secara tekstual ayat dan hadis di atas, tidak membenarkan kaum perempuan menjadi pemimpin dalam berbagai medan dan wilayah, termasuk menjadi kepala negara (presiden). Ahli fiqh klasik sepakat bahwa dalam rumah tangga, suamilah yang menjadi pemimpin bagi isterinya. Di dalam masyarakat kaum laki-laki juga bertindak sebagai pemimpin.

${ }^{14} \mathrm{Abū}$ 'Abd. Allāh Muhammad ibn Ismā’̄il ibn Ibrāhim ibn al-Mugīrah ibn al-

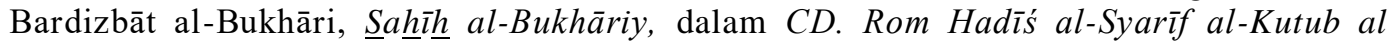
Tis'ah, Kitab al-Maghāzi hadis nomor 4073. 
Sementara itu, diketahui bahwa kaum perempuan sejak kedatangan Islam melalui Alquran dan hadis juga, digambarkan sebagai kaum yang aktif, sopan, dan terpelihara akhlaknya. Bahkan dalam Alquran, figur ideal seorang muslimah disimbolkan sebagai pribadi yang memiliki al-istiqlāl alsiyāsah, atau kemandirian politik, ${ }^{15}$ seperti figur Ratu Bulqis yang memimpin kerajaan superpower ('arsyun 'azhìm), ${ }^{16}$ memiliki kemandirian ekonomi (al-istiqlāl al-iqtisādiy). ${ }^{17}$ Perempuan juga digambarkan sebagai figur perempuan pengelolah peternakan sebagaimana dalam kisah Nabi Mūsa as di Madyan. ${ }^{18}$ Bagi perempuan yang sudah menikah, memiliki kemandirian dalam menentukan pilihan pribadi, al-istiqlāl al-syakhsi yang diyakini kebenarannya, sekalipun berhadapan dengan suami, ${ }^{19}$ atau menentang pendapat orang banyak (publik opinion) bagi perempuan yang belum menikah. ${ }^{20}$ Lebih dari itu, Alquran juga, mengizinkan kaum perempuan melakukan gerakan "opisisi” terhadap segala bentuk sistem yang bersifat tirani demi tegaknya kebenaran. ${ }^{21}$

Berkenaan dengan itulah, maka bila ditinjau dari konsep fiqh, dipahami bahwa ajaran Islam senantiasa memberikan kebebasan yang begitu besar kepada kaum perempuan, sehingga tidak mengherankan jika pada masa Nabi saw ditemukan sejumlah perempuan yang memiliki kemampuan dan prestasi cemerlang seperti yang dimiliki kaum laki-laki. Berkenaan dengan ini, praktis bahwa kaum perempuan juga diberikan kesempatan untuk menjadi pemimpin. Hanya saja, usaha Nabi saw dalam mewujudkan gender equality belum mencapai tingkat maksimal karena masa kenabian sangat singkat, yakni 22 tahun. Dengan kata lain, masa nabi terlalu singkat untuk melanggengkan relasi perempuan dan laki-laki yang adil dan setara di masyarakat. Setelah Nabi saw wafat, maka usaha itu harus

\footnotetext{
${ }^{15}$ Lihat QS. al-Mumtahanah (60): 12

${ }^{16}$ Lihat QS. al-Naml (27): 23

${ }^{17}$ Lihat QS. al-Nahl (16): 97

${ }^{18}$ Lihat QS. al-Qashash (28): 23

${ }^{19}$ Lihat QS. al-Tahrīm (66): 11

${ }^{20}$ Lihat QS. al-Tahrīm (66): 12

${ }^{21}$ Lihat QS. al-Taubah (9): 71
} 
dilanjutkan oleh umatnya dengan tetap mengacu pada nas-nas ajaran agama (Islam).

Sebagai jalan keluarnya, ayat dan hadis di atas harus ditinjau dari sudut fiqh dengan melihat latar belakang turunnya ayat dan latar belakang disabda-kannya hadis tersebut, yang secara kontekstual pada saat itu kondisi kaum perempuan tidak sama kondisinya di era kekinian. Dengan kata lain, subtansi nash tadi, bukan berupa kalimat larangan (nahiy), tapi hanya khabariyah (berita). Karena itu, hukum haram (larangan) pun tidak memiliki signifikansi yang akurat.

Tidak berlebihan jika dikatakan bahwa pemimpin perempuan bukanlah mani' (larangan) dalam fiqh Islam. Jadi makna pemimpin yang dilarang menurut pemahaman fiqh sebenarnya adalah perempuan yang berkuasa secara absolut seperti Raja atau Kaisar zaman dahulu. Bila dikaitkan dengan negara Indonesia sekarang yang menganut sistem demokrasi maka kepemimpinan kaum perempuan dibolehkan. Sebab, berdasarkan demokrasi, kekuasaan negara dibagi menjadi tiga, yakni kekuasaan ekskutif (pemerintahan), kekuasaan legislatif (pembuat undangundang), dan kekuasaan yudikatif (kehakiman). Jadi jika seorang perempuan menjadi presiden di negara ini yang kekuaasannya hanya terbatas di bidang eksekutif, tidaklah dalam pengertian pemimpin yang dilarang, apalagi jika hanya menjadi menteri, atau pemimpin instansi tertentu saja, semuanya tentu dibolehkan.

Pemahaman fiqh seperti di atas sangat cocok dalam konteks negara republik Indonesia, dan pada gilirannya memberi peluang bagi kaum perempuan dan laki-laki untuk sama-sama berpeluang meraih kedudukan dan jabatan tinggi di tengah-tengah masyarakat, baik itu hakim, anggota parlemen, atau jabatan tertinggi sekalipun yakni sebagai kepala negara. 


\section{Penutup}

Berdasar dari uraian-uraian yang telah dikemukakan, maka dapat disimpulkan bahwa fiqh adalah ilmu tentang hukum-hukum syariat yang bersifat amaliyah, yang diambil dari dalil-dalilnya yang terperinci. Dari sini kemudian dirumuskan bahwa fiqh perempuan memiliki beberapa dua konsep.

Pertama, fiqh perempuan adalah hukum-hukum amaliyah dalam melaksanakan syariat, misalnya masalah wali nikah bagi kaum perempuan yang hendak melaksanakan perkawinan. Kedua, fiqh perempuan adalah dalil-dalil tentang hukum tentang, misalnya dalil tentang kepemimpinan kaum perempuan. Karena fiqh perempuan berkaitan dengan hukum syara' dan dalil naqli maupun aqli, maka secara esensial fiqh perempuan dalam artian pemahaman tentang eksistensi kaum perempuan merupakan hasil ijtihad yang disebut dengan fiqh ijtihädiy.

Sebagai konsekuensinya, perempuan dalam pemahaman fiqh harus didudukkan pada posisi yang sebenarnya, serta memberi mereka peranan bukan saja dalam kehidupan rumah tangga, tetapi juga dalam kehidupan ber-masyarakat. Konsep fiqh perempuan dalam rumah tangga mengutamakan adanya mu'āsyarah bi al-ma'rūf. Sedangkan dalam masyarakat mengutamakan kesetaraan dalam memperoleh kedudukan (jabatan) sebagaimana kaum laki-laki. 


\section{Daftar Pustaka}

Alquran al-Karīm

Bukhāri, Abū 'Abd.Allāh Muhammad ibn Ismā'̄̄l ibn Ibrāhim ibn alMugīrah ibn al-Bardizbāt. $\underline{S} a \underline{h} \underline{\bar{h}} \underline{\mathrm{h}}$ al-Bukhāriy, dalam CD. Rom Hadī's al-Syarīf al-Kutub al Tis'ah.

Departemen Agama RI. Alquran dan Terjemahnya. Jakarta: Proyek Pengadaan Kitab Suci Alquran, 1992.

Departemen Pendidikan dan Kebudayaan. Kamus Besar Bahasa Indonesia. Cet. III; Jakarta: Balai Pustaka, 1994.

Haq, Hamka. Syariat Islam; Wacanadan Penerapannnya. Cet. II; Makassar: Yayasan Ahkam, 2003.

Ibn Hanbal, Abū Ahmad Muhammad. Musnad Ahmad dalam CD. Rom Hadīś al-Syarīf al-Kutub al Tis'ah, Kitab Maktabat al-Hadīś alSyarīfah.

Ibn Zakariyah, Abū Husain Ahmad bin Fāris. Maqāyis al-Lughah, juz IV. Bairūt: Dār al-Jail, 1981

Kompilasi Hukum Islam, pasal 20, ayat (1)

Muhammad, KH. Hussein. Fiqh Perempuan. Yogyakarta: LkiS, 2001.

Mulia, Siti Musda. MuslimahReformis, Perempuan Pembaru Keagamaan. Cet I. Bandung; Mizan, 1425 H/ 2005 M.

Munawwir, Ahmad Warson. Kamus al-Munawwir Arab Indonesia, Edisi II, Cet XXV. Surabaya: Pustaka Progressif, 1997.

Republik Indonesia, Undang-Undang Hak Asasi Manusia, pasal 45 s.d. 51. Zahrah, Abū. Ushūl al-Fiqh. Mesir: Dār al-Fikr al-‘Arabiy, t.th. 